\title{
THE ONE-TERM PREDICATION FOR DEICTIC IDENTIFICATION IN HAUSA
}

\author{
Mahamane L. Abdoulaye \& Salifou Barmou, \& Saoudé Souley Bida \\ Abdou Moumouni University \& EUCAP Sahel Niger
}

\begin{abstract}
This article describes a type of non-verbal predication (NVP) with a single term called "deictic identification" (for example, Abdù nee 'it's Abdu') and which, in its basic function, is used to identify a referent present in the immediate spatial environment of the speaker. The paper shows that the one-term sentences must be distinguished from ordinary twoterm specificational or equative sentences (for example, ùban Muusaa Abdù nèe 'Musa's father is Abdu' and wannàn Abdù nee 'this is Abdu'). Indeed, the paper in particular shows that when the two types of constructions are used in non-assertive contexts, they can select two different replacive copulas. The paper also shows how the basic one-term deictic constructions acquired extended, non-deictic uses, including uses in focus-fronting constructions, where the immediate external environment is not always relevant. The paper proposes that copula nee/ cee is the sentence predicate in one-term deictic identification and is hence comparable to other one-term non-verbal predicates in Hausa, such as the presentational gàa (for example, gàa Abdù 'here is Abdu').
\end{abstract}

Keywords: Non-verbal predications, Hausa, Deictic identification, Copula, Focus

\section{Introduction}

According to Payne (1997: 113) non-verbal predications (NVPs) are interesting for their own sake as a component of languages, but also because they are frequently recruited for the formation of larger syntactic constructions, such as the focus or wh-question constructions, or in the formation of tense and aspect markers. To these reasons, one can add the fact that NVPs (nominal, existential, possessive predications, etc.) are among the most common constructions in everyday usage and also the most useful for the child in acquisition (cf. Brown 1973: 274, cited by Steinberg 1982: 154). The main objective of this article is to provide an overview of NVPs in Hausa through a review of the linguistic literature. The article then focuses on one type of NVP that has been neglected in Hausa studies as well as in general linguistics and which has been suggested by Stassen (1997: 100) and taken up in Abdoulaye (2007: 245f) under the name "deictic identification". This type of predication has a single term in a construction "NP + Copula" (cf. Abdù nee 'it's Abdu') and must be clearly distinguished from the two-term nominal predication, specification, or identity statement (cf. ùban Muusaa Abdù nèe 'Musa's father is Abdu', wannàn Abdù nee 'this is Abdu'), even if on a first look both seem to use the same copula nee/ cee.

On the methodological level, it is of course not easy to define exactly what a NVP is. For example, Payne (1997: 112) proposes that NVPs have no semantically rich verb, i.e., a verb capable of conveying the semantics of the predication. For example, by comparing the copula be and the 
verb eat, we have an idea of the action expressed by the verb eat but we need to look at the whole predication built around copula be to understand its meaning. In other words, with the same copula, $A b d u$ is the director expresses an identification, while $A b d u$ is in the room expresses a localization. In the traditional logical approach (see Creissels 2006: 343), in these examples, it is the nominal the director and the prepositional phrase in the room that are the non-verbal predicates, expressing a property verified by the referent of the nominal $A b d u$ (see Wolff 1993: 494 for the opinion that the Hausa copula nee/ cee is "almost semantically empty"; see also Pustet 2003: 5 and the references she cites for a general definition of the copula as a semantically empty linguistic element). This approach, however, is rather restrictive, applying well to nominal and adjectival predications, but less so to other types of non-verbal predications. Thus, considering the criterion of the semantic poverty of the copula, Payne (1997: 113) notes that the different types of NVPs will not be classified in the same category (hence his using the expression "predicate nominals and related constructions", thus avoiding the all-encompassing expression "non-verbal predications" as used, say, in Creissels 2006). For Payne, NVPs can be expressed by more or less semantically rich copulas, in a continuous variation from "meaningless" copulas to copula-verbs with a clear semantic charge. Typical representatives of the first category are nominal and adjectival predications, which in many languages involve a predicate (a nominal or an adjective) and its subject bound by a "meaningless" copula. In these cases, the copula can be limited to a purely syntactic role, i.e., it serves as a link between the subject and the non-verbal predicate, a function which many languages can sometimes dispense with (see Payne 1997: 114, Pustet 2003: 3). Possessive predications may represent the second category, since they can have a regular verb in some languages and a defective copula in other languages. One of the consequences of Payne's approach is that NVP types with semantically rich copulas can be analyzed as having a logical predicate (the semantically rich copula) with its two logical arguments. Nonetheless, it should be noted that more specialized discussions nowadays make a distinction in English between nominal predications and equative or identity statements, even if both involve the structure "NP1 be NP2". Indeed, by definition, equative or identity statements do not have a property-attributing nominal predicate, rather, they have two referring expressions as logical arguments around the copula be, which in this case is the logical predicate with the meaning 'is equal to' (see Roy 2013: 8 and the references she cites, see also Declerck 1988: 1 on the many types of be's in English). This proposal implies the existence of at least two copulas be. In Section 3, we will propose that the Hausa one-term deictic identification construction uses the same copula predicate nee/ cee one finds in equative predications, but with one logical argument. For this reason, in our overview of Hausa NVPs in the next section, we adopt the finedgrained typology of Declerck (1988) who distinguishes at least four major types of nominal "NP1 be NP2" predications (see Section 2.1). Unless otherwise indicated, the examples discussed in the paper come from our own grammatical judgments or from informants.

The article is structured as follows. Section 2 presents an overview of Hausa NVPs through a review of the literature. Section 3 describes the characteristics and uses of the deictic identification construction. 


\section{Overview of non-verbal predications in Hausa}

Hausa being a rather well-known language, the main types of NVPs are well described, particularly in recent works such as Abdoulaye (2006), Caron (1991), Green (1997, 2004), Green and Jaggar (2001), Jaggar (2001), Newman (2000), and Wolff (1993). The studies in Green (1997, 2004), Green and Jaggar (2003) in particular have focused on the nee/ cee-based copular sentences that have a "NP1 + NP2 + nee/ cee" structure, corresponding to the "NP1 + be + NP2" sentences in English. These types of sentences have generated a lot of controversies in the linguistic literature. Indeed, there are many typologies proposed, varying in the types distinguished, their number, and their relationship. For example, while Declerck (1988) distinguishes about six (major and minor) types of "NP1 + be + NP2" sentences in English, other researchers distinguish substantially more types (see the 14 semantic types proposed in Hengeveld 1992: 116; see also Mikkelsen 2005: 6 and the references she gives). Regarding the relationship between types, the case of the specificational sentences is illustrative. Indeed, depending on the investigator, specificational clauses can be an independent type, have affinity with equative clauses, or with the nominal predication clauses (see the discussions in Mikkelsen 2005: 2ff, 60ff, den Dikken 2006: 70ff, and particularly Declerck 1988: 2f, 110ff). Finally, another difficulty is that some works use different (sometimes idiosyncratic) names for the same types of constructions (see Higgins 1979, as cited in Mikkelsen 2005: 48). To simplify our presentation of the "NP1 + NP2 + nee/ cee" sentences in Hausa, we adopt Declerck's (1988) typology and definitions (see also Green 2004: 7, who similarly uses Declerck's typology in her study of copula nee/ cee).

To provide a background as exhaustive as possible, this section also reviews the other nonverbal sentences in Hausa (localization, possession, etc.) built with copulas or predicates other than nee/ cee, particularly since they will be referred to from time to time in the rest of the paper. Regarding these NVPs, the section relies on the main types found in Hausa linguistic literature. The types of NVPs reviewed can be summarized as follows (we have retained only the first four major types of "NP1 + be + NP2" sentences found in Declerck's typology):

Table 1: Types of NVPs in Hausa

- Sentences built around copula nee/ cee

Nominal predication (or "nominal sentence", mainly for classification)

Specification (identification by value assignment to a variable)

Equative (Declerck's “descriptionally-identifying”)

Identity statements (alternate names of same referent)

Adjectival predication

- Non-verbal predications built with copulas or predicates other than nee/ cee

Locative predication (copula -nàa)

Existential predication (predicate dà or àkwai)

Presentational predication (predicate gàa)

Possessive predication (complex predicate $-n a ̀ a+d a ̀)$

It may be noted that Table 1 refers to the use of the sentence types in assertive contexts (since in non-assertive contexts, as we will see in due course, almost all copulas and predicates are replaced with the non-assertive copula/ predicate kèe/-kè).

The following subsections discuss first the "NP1 + NP2" sentences (nominal predications, specification sentences, equative sentences, and identity statements; see Section 2.1), then the 
adjectival predications (Section 2.2), and finally each of the NVPs that are not based on the copula nee/ cee (Sections 2.3-2.6).

2.1. Copular "NP $1+$ NP $2+$ nee/ cee" sentences. This subsection presents the sentences in Hausa involving two NPs and the copula nee/ cee. These sentences express nominal predication (mostly classification), specification, equative predication, and identity statements. We also group them together because most languages have no formal distinction between them (see Declerck 1988: 4, Payne 1997: 114), which is the case in Hausa, where they are all expressed with the copula nee/ cee in a "NP1 + NP2 + nee/ cee" structure. We first present the nominal predication sentences. According to Declerck (1988: 55), in nominal predications a noun (the complement NP) predicates a property (characterization, role, function, class-membership) of the referent of the subject NP. When they express class-membership, nominal predications mark the relation of proper inclusion between the referent of the subject (NP1) and the category denoted by the nominal predicate, the NP2 (see for example Payne 1997: 114). Generally, the nominal subject is definite/ specific while the nominal predicate is indefinite/ generic. Some examples with simple assertion are given in the following (for similar examples and more detailed discussions, see also Caron 1991: 134f, Green 2004: 1, 17, Jaggar 2001: 458, Newman 2000: 160-161, 544-545 and Wolff 1993: 494): ${ }^{1}$

$\begin{array}{llll}\text { (1) a. } & \begin{array}{l}\text { Paarì bàbba-n gàrii nèe. } \\ \text { Paris big-of } \\ \text { 'Paris is a big city.' }\end{array} & \begin{array}{l}\text { town COP } \\ \text { b. }\end{array} \\ \text { b. } & \begin{array}{l}\text { Abdù manòomii nèe. } \\ \text { Abdu farmer } \\ \text { 'Abdu is a farmer.' }\end{array}\end{array}$

In sentences (1), the copula is nee, with a polar tone tuned to the preceding tone. The copula also agrees in gender and number so that nee is used with masculine and plural predicate nouns and cee with feminine predicate nouns (see Newman 2000: 160 for more details). Given the fact that the two NPs in predicational sentences fulfill different functions, the examples in (1) do not allow for the transposition of the two nouns (while keeping the same semantic or pragmatic implications). Indeed, the two NPs are different in that the subject is referential (or can license a co-indexed referential expression later in the sentence), while the predicate NP cannot be referential or be co-indexed with a referential expression (see the discussion in Declerck 1988: 56ff and references cited there). For the classifying nominal sentences, it may be noted that some authors distinguish between classmembership (such as the examples in (1)) and class-inclusion (whales are mammals), though this never translates into distinctive formal expression (see Lyons 1968: 389, as cited in Declerck 1988: 1, n2; see Caron 1991: 123 on Hausa). We have indicated that examples (1), with copula nee/ cee, are used to express simple positive assertion. In non-assertive clauses (presupposed causal and consequent adverbial clauses, relative clauses, and out-of-focus clauses of sentences with a focused or wh-constituent), another copula kèe/ $-k \grave{e}$ is used, as seen in the following example with focalization:

1 It may be noted that in Hausa, in certain fixed expressions, proverbs and sayings, copula nee/ cee in nominal sentences can be omitted, as reported, amongst others, in Caron (1991: 123), Newman (2000: 164f), and Wolff (1993: 497f). 
(2)

$\begin{array}{lccl}\text { Abdù } \quad \text { (nee) } & \text { kèe } & \text { manòomii. } \\ \text { Abdu COP } \quad \text { COP } & \text { farmer } \\ \text { 'It's Abdu that is a farmer.' } & \end{array}$

In (2), the nominal Abdì is focus-fronted and optionally followed by a focus-associated copula nee/ cee (derived from copula nee/ cee; see the comments around Table 2), while the copula kèe/-kè appears in the out-of-focus clause. Syntactically, kèe/-kè differs from copula nee/ cee in coming before the NP2 in the predication, as shown in example (2). Besides nominal predications, virtually all other non-verbal predications use copula kèe/-kè in non-assertive contexts, in replacement for their specific copulas or predicates of assertive contexts (see the discussion in Section 3.1; see also the comments around Table 2). It should also be noted that examples (1-2) give only the basic structures and Hausa NVPs in general have a rather varied syntax that cannot all be discussed in this paper (see Caron 1991: 123-143, amongst others, for more detailed descriptions).

The rest of this subsection discusses three types of non-verbal sentences that in many general works are conflated under the label "equational", "equative", or "identificational" sentences (see for example Payne 1997: 114, Creissels 2006; for a summary discussion of this issue see Declerck 1988: 2-3). The same conflation is also made in virtually all Hausa studies except for Green $(2004,2007)$ and Green and Jaggar (2003). In this paper we adopt Declerck's typology and distinguish between specificational sentences, descriptionally-identifying sentences, and identity statements. According to Declerck (1988: 2), a specificational sentence specifies a value, expressed by one NP, for a variable (expressed by the other NP). This can be illustrated in the following child story where some children, out looking for "Ali the Leper", actually stumbled on him:

\begin{tabular}{|c|c|c|c|c|c|}
\hline a. Children: & $\begin{array}{ll}\text { Maalàm, } & \text { Àali } \\
\text { Sir } & \text { Ali }\end{array}$ & $\begin{array}{l}\text { Kuturuu } \\
\text { Leper }\end{array}$ & $\begin{array}{l}\text { mu-kèe } \\
1 \mathrm{p}-\mathrm{RI}\end{array}$ & $\begin{array}{l}\text { neemaa. } \\
\text { looking.for }\end{array}$ & \\
\hline & 'Sir, we are lookin & for Ali the & per.' & & \\
\hline b. Ali the Leper: & $\begin{array}{l}\text { Àalî-n } \\
\text { Ali-DF }\end{array}$ & $\begin{array}{ll}\text { nii } & \text { nèe, } \\
1 \mathrm{~s} & \mathrm{COP}\end{array}$ & $\begin{array}{l}\text { àmmaa } \\
\text { but }\end{array}$ & $\begin{array}{ll}\text { kuturû-n } & \text { ùba-n-kù } \\
\text { leper-DF } & \text { father-of-2p }\end{array}$ & $\begin{array}{ll} & \text { nee. } \\
\text { p } & \text { COP }\end{array}$ \\
\hline
\end{tabular}

According to Declerck (1988: 6f), specificational sentences most often answer a wh-question. In (3a) the underlying question from the children would be wàanee nèe Áali Kuturuu? 'who is Ali the Leper?', which Ali, of course, split distinctly into 'who is Ali?' and 'who is the leper?' In (3b) the answer to the question 'who is the leper?' restates the variable, kuturûn 'the leper', for which a value, ùbankù 'your father', is specified. According to Declerck (1988: 10f), a specificational sentence allows the speaker to pick out a valid referent (or a list of referents) from a set. Hence the variable is generally a definite (see Declerck 1988: 19) but non-referring NP. Most researchers also note that in specification (and also in descriptionally-identifying sentences and identity statements), the two NPs are typically reversible (see Declerck 1988: 40-47). So, the relevant part of sentence (3b) can be reversed as àmmaa ùbankù kuturûn nee 'but your father is the leper', which also answers the question 'who is the leper?'. It should be noted that answers to normal wh-questions in Hausa frequently take the form of focused sentences (see wàanee nèe kuturûn? 'who is the leper?', ùbankù nèe kèe kuturûn 'it's your father that is the leper', but non-focused sentences are acceptable as well (see Jaggar 2001: 496, Green and Jaggar 2003: 205 who consider such answers to express the insitu focus). Further examples of specificational sentences are given in the following (for additional 
examples that can be interpreted as specificational sentences, see also Caron 1991: 124, Green 2004: 19, Jaggar 2001: 458, Newman 2000: 160-161, and Wolff 1993: 494):
a.
Bàbban birni-n
Fàransà
Paarìs
nee. (= Paarìs bàbban birnin Fàransà nee)
capital-of
France
Paris
COP
'The capital city of France is Paris.' (= 'Paris is the capital city of France')
$\begin{array}{lll}\text { b. Uwa-r Bàlki } & \text { Hàdiizà cèe. } \\ \text { mother-ofBalki } & \text { Hadiza } & \text { COP }\end{array}$
'Balki's mother is Hadiza.' (= Hadiza is Balki's mother)

In examples (4a-b), again a speaker picks out the correct referent for a variable NP, answering, respectively, the questions 'what is the capital city of France?' and 'who is Balki's mother?'. As seen in the translation, these questions can be answered with the NPs in either order. In Hausa however, the reversed sentences may not always answer the same question. For example, the reverse of sentence (4a), Paarìs bàbban birnin Fàransà nee 'Paris is the capital city of France', would only answer the question miinee nèe Paaris? 'what is Paris?').

According to Declerck (1988: 95) the vast majority of copular sentences are nominal predications or specificational sentences. Besides these two however, there are minor types, one of which is what he calls the "descriptionally identifying" sentences, which have elsewhere been called "identificational", "equational", or "equative" sentences. Declerck illustrates them with the following English sentences (in this paper, we will use the term "equative", following Green 2004):

(5) a. [Who's that man?] That man is John's brother.

b. [Mike? Who's Mike?] Mike is my brother.

According to Declerck, the sentences in (5), although they apparently answer wh-questions, do not in fact specify a value for a variable NP (i.e., the speaker is not picking out referents from a set). Indeed, contrary to a variable NP, the subject NPs that man in (5a) and Mike in (5b) are fully referring NPs. According to Declerck (1988: 100), equative (descriptionally identifying) sentences answer the request "tell me more about $X$ " where " $X$ " is already identified (visible in the immediate setting, as in most cases, or identified through a proper name). For Hausa, one can consider the following examples (sentence (6c) from Green 2004: 20; for further examples that can be interpreted as equative sentences see Caron 1991: 124, Jaggar 2001: 458, Newman 2000: 160-161 and Wolff 1993: 494):

$\begin{array}{lll}\text { (6) a. Nii Àali nèe. } & \\ & \text { 1s Ali COP } \\ \text { 'I am Ali.' } & & \\ \text { b. Wannàn Àali nèe. } & \\ \text { this Ali COP } \\ \text { 'This is Ali.' }\end{array}$

Green (2004) considers that equative sentences in Hausa are not syntactically different from specificational sentences and uses the term "equative sentences" to refer to them. Sentences (6a-c), 
respectively, answer the questions wàa kakè?/ wàanee nèe kai? 'who are you?' for (6a), wàanee nèe wannàn? 'who is this?' for (6b) and wàanee nèe mùtumin cân? 'who is that man there?'. We will come back to this type of sentences in the next section.

The final type of nominal sentences we review is identity statement sentences. According to Declerck (1988: 110), in English "NP1 + be + NP2" identity statements can be paraphrased as "NP1 is the same (person/object) as NP2", which is not case with predicational, specificational, or equative sentences. Much cited examples of identity statements in English include the morning star is the evening star, Clark Kent is Superman (see also Mikkelsen 2005: 55f and references cited there, Declerck 1988: 40-43, 110ff). Examples of identity statements in Hausa can be as follows (for more examples see Caron 1991: 124):

$$
\begin{aligned}
& \text { Ìiro Ìbraahìm nèe. (= Ìbraahìm Ìiro nèe) } \\
& \text { Iro Ibrahim } \quad \text { COP } \\
& \text { 'Iro is Ibrahim.' (= 'Ibrahim is Iro') }
\end{aligned}
$$

Sentence (7) gives two alternate names (of the William $\sim$ Bill type) so that anybody called Iro can also be called Ibrahim and vice versa. Identity statements are fully reversible, as indicated in (7).

2.2. Adjectival predications. In adjectival predications, the predicate is a qualifying adjective, a numeral or a quantifier. According to Payne (1997: 120), in most languages adjectival predications generally have the same morphosyntax as nominal predications. This is explained by the fact that in many languages the morphosyntactic differences between the category of nouns and that of qualifying adjectives are not very important. In Hausa, the class of basic adjectives is restricted (see Schachter 1985: 15). But more recently, Newman (2000: 22-33) has shown that the adjective class is well-established, with several sub-classes and various processes for deriving adjectives from other lexical categories. Caron (1991: 143) suggests that adjectival predications answer questions containing the interrogative adverb kàakàa 'how'. Some examples are given in the following (for similar examples, see also Caron 1991: 140, Green 2004: 18, Jaggar 2001: 458, and Newman 2000: 160):

$\begin{array}{llll}\text { (8) a. } & \begin{array}{l}\text { Kàre-n nàn bakii } \\ \text { dog-DF here bè } \\ \text { 'This dog is black.' }\end{array} & \begin{array}{l}\text { bOP } \\ \text { black }\end{array} \\ \text { b. } & \begin{array}{l}\text { Paarì bàbba } \\ \text { Paris big } \\ \text { 'Paris is big.' }\end{array} & \text { COP }\end{array}$

Thus, adjective predications use the copula nee/ cee in a basic structure "NP + AdjP + COP". Like nominal predications, adjective predications use the copula kèe/-kè in non-assertive contexts.

2.3. Locative predications. A static location expression establishes a landmark or background where another element is located. In Hausa, the locative predication with simple assertion uses the copula -nàa that we will gloss as 'be.LOC', and which is usually completed by a preposition specifying the nature of the contact or the orientation between the landmark and the localized entity. The predication uses the basic structure "NP + (pronoun) + COP + NP / PP / AdvP". Some examples are given in the following (for similar examples, see also Abdoulaye 2006: 1150, Caron 1991: 126, Jaggar 2001: 172, 174, Newman 2000: 577 and Wolff 1993: 428): 


9) a. Abdù ya-nàa cikin daakì.
Abdu 3ms-COP in
'Abdu is in the room.'
b. Abdù ya-nàa dakà/ can.
Abdu 3ms-COP in.room/ there
'Abdu is in the room/ over there.'
c. Abdù ya-nàa kàasuwaa.
Abdu 3ms-COP market
'Abdou is at the market.'

As the examples show, the locative predicate can assume several forms: either a nominal (or a pronoun) with or without a preposition, as in $(9 \mathrm{a}, 9 \mathrm{c})$, or a derived adverb or demonstrative adverb, as seen in (9b). Locative predications are also sensitive to pragmatic and polarity contexts and use the copula kèe/-kè 'be.LOC' in non-assertive clauses and the copula bâa 'be.LOC.NEG' in negation. Just like copula kèe/-kè, copula bâa is auxiliarized in verbal predications and used in most tense/ aspect categories as the general negative marker.

2.4. Existential predications. According to Payne (1997: 123), existential predications typically require a locative complement and that sentences that predicate for the existence of God, without a locative complement, are exceptional. In Hausa, however, the existential predication differs from the locative predication by the fact that it uses a different copula predicate and the fact that it does not require - but allows - a locative complement. Many authors have also noted that the nominal subject whose existence is predicated tends to be indefinite, while the subject of a locative predication tends to be definite (see Caron 1991: 132 for Hausa and Freeze 1992: 557, Hengeveld 1992: 119 and references cited there, and Payne 1997: 123 for a general discussion). In Hausa, existential predications use the predicates àkwai, dà (or their combination dà àkwai or dàkwai) and the negative predicates $b \hat{a} a$ and baabì in a structure "PRED + NP", with a possible locative complement specified. Some examples are given in the following (for similar examples, see also Abdoulaye 2006: 1123-1127, Caron 1991: 126, Jaggar 2001: 464f, Newman 2000: 178 and Wolff 1993: 493f; data (10c-d) adapted from Moussa-Aghali 2000: 15, 39):

$\begin{array}{ll}\text { (10) à } & \text { Àkwai Allàh! } \\ & \text { exist God } \\ & \text { 'God exists!' }\end{array}$

b. Dà wa-ni kidâa dà su-kèe yîi. exist one-3ms music that $3 p-R I$ do

'There is a kind of music they play.'

$\begin{array}{lllllll}\text { c. Kàajîn } & \text { nan } & \text { kùwa, baabù } & \text { haalii } & \text { à } & \text { yankàa } & \text { su. } \\ \text { chickens-DF } & \text { those } & \text { as.for exist.NEG } & \text { opportunity } & \text { one.SBJ } & \text { slit } & 3 p\end{array}$

'As for those chickens, there is no way one could kill them.'

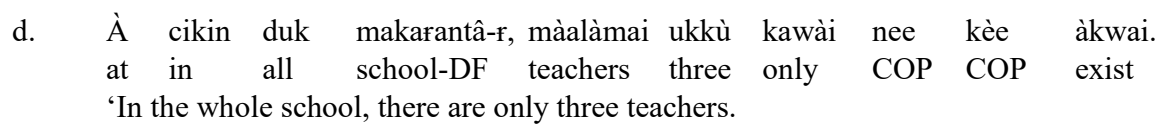

Predicate àkwai is almost exclusively used in existential predications (see Abdoulaye 2006: 1139 for a possessive use), whereas the particle dà has many other uses. As with other NVPs, existential 
predications are sensitive to pragmatic context, but combine the existential predicates with the nonassertive copula kèe/-kè, as illustrated in (10d) where the predicated NP (màalàmai ukkù 'three teachers') is focused. The existential predication can also be expressed with the locative copula -nàa augmented with the demonstrative adverb nan 'there' with the special sense of 'be around, be available' (cf. French il est là 'he is around'; see also Abdoulaye 2006: 1153, Garba 1989: 126).

2.5. Presentational predications. Payne (1997: 123) does not seem to make a strong distinction between existential and presentational predications. Indeed, he does not discuss the presentational predications and even claims that existential predications typically have a "presentative" function and serve to introduce participants into the discourse stage. In Hausa, most authors agree that for the presentational function, there exists a special construction using the predicate gàa in a basic structure "gàa + NP". Also, most researchers think that the structure "gàa + NP" derives from the imperative statement with the verb ga/ganii 'see', and is therefore comparable to French voici/voilà 'here is'. Some examples are given next (for similar examples, see also Caron 1991: 131, Jaggar 2001: 468f, Newman 2000: 181 and Wolff 1993: 493; data (11b-c) adapted from Moussa-Aghali 2000: 47, 30):

$\begin{array}{llll}\text { (11) a. Gàa } & \text { Abdù } & \text { nan } & \text { tàhe. } \\ \text { here.is } & \text { Abdu } & \text { there coming }\end{array}$

'There is Abdu[,] coming.'

$\begin{array}{lllll}\text { b. Sai gàa } & \text { mootàa } & \text { taa } & \text { zoo } & \text { daukà-r-mù. } \\ \text { then here.is } & \text { vehicle } & \text { 3fs.CPL } & \text { come } & \text { taking-of-1p }\end{array}$

'Then here comes a vehicle that will take us.'

c. Baayan hakà kuma, gidâ-n gàa shi ràabe dà gida-n kasòo. beside this also house-DF here.is $3 \mathrm{~ms}$ leaning with prison-of prison 'Beside this, there is also the fact that the house is right next to a prison.'

Sentence (11a) gives the typical usage of the presentational predication, where the subject NP directly refers to an entity in the immediate spatial environment of the speaker, usually implying a visual contact for both speaker and hearer. This ties in with Caron's (1991: 131) statement that the particle gàa "places [the referent of] a term within the speaker's sphere of influence" (by contrast, existential predications naturally do not have such a restriction). In narratives, the NP complement of gàa can refer to an entity, a fact or situation (or even an event) described in the narrative setting, as seen in (11b-c), respectively. This illustrates another case where a linguistic element with a basic deictic function can acquire extended, non-deicitc usages. As noted in Caron (1991: 131), presentational predications, unlike existential predications, do not have a negative form and cannot be focused or questioned (with the exception of echo questions such as gàa mii? 'here is what?' and their answers as littaafii na cèe gàa shi 'it is (about) the book I just said here it is'). Presentational statements can also use other predicates such as the perception verbs $j i$ 'feel', dìibi 'look', and hîn 'take', which all mean 'look at $\mathrm{X} /$ here is $\mathrm{X}$ ' when used in presentational context.

2.6. Possessive predications. Of all NVPs, the possessive predication is certainly the most complex, both globally and in individual languages. For example, Payne (1997: 126) shows that depending on the language, possessive predications can use either a verb (have in English, avoir in French, etc.), a nominal predication copula (Mandarin), a locative predication copula (Estonian), or an existential predicate (Turkish, Mandarin). However, for Heine (1997) most languages choose a few 
schemas or constructions for their possessive predication from a set of eight universally available source schemas. Of the few schemas a language selects, one comes to dominate and becomes the most grammaticalized and hence expresses the most neutral, most general possessive sense (for the criteria of most grammatical possessive construction in a language see Heine 1997: 33). In Hausa the most grammaticalized positive possessive predication is based on the localization copula -nàa

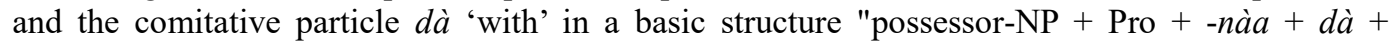
possessed-NP", where -nàa is variously analyzed as the "imperfective" marker (Jaggar 2001: 470, Newman 2000: 222, 543), a locative "be-(at-a-place)" copula (Caron 1991: 136, Wolff 1993: 112), a type of be or exist predicate (Abraham 1959: 11). The particle dà is almost always taken to be the comitative 'with' (except in Abdoulaye 2006: 1145, where it is taken to be an existential predicate). The most general negative possessive construction uses the negative existential predicate bâa 'exist.NEG' combined with a comitative particle $d \grave{a}$ ' with' in a basic structure "possessor-NP + bàa + Pro + dà + possessed-NP" (lit. "NP + exist.NEG + with + NP"). Some examples are given next (for similar examples, see also Abdoulaye 2006: 1146ff, Caron 1991: 136, Jaggar 2001: 470f, Newman 2000: 543-544 and Wolff 1993: 495):

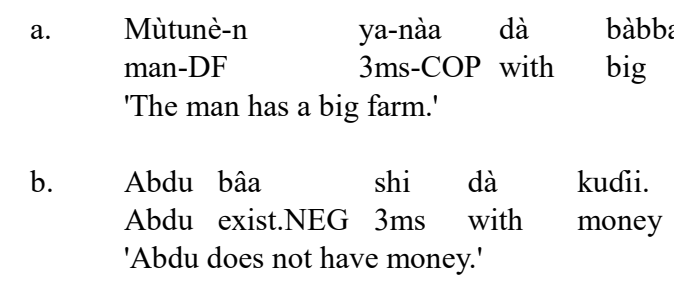

According to Caron (1991: 136), the nominal referring to the possessor is strongly determined, which is confirmed by the examples in (12). It should be noted that the possessive predication based on $n a ̀ a+d \grave{a}$ and its negative counterpart are pragmatically and semantically neutral and contrast with possessive predications using other schemas or using strong verbs. The alternative constructions are pragmatically or semantically marked (for example, a possessive verb such as màllakàa 'own, possess' implies a tangible positive possession, say, a car).

To conclude this section, we have reviewed five major types of NVPs based on copula nee/ cee (nominal, specificational, equative, identity statements, and adjectival sentences) and four other NVPs based on other types of copulas/ predicates (locative, existential, presentational, and possessive predications). ${ }^{2}$ To these predications, the next section adds another one, the one-term

2 Wolff $(1993: 454,493)$ analyzes the comparative construction with gwàmmà 'rather, much better' (and its variants) as a non-verbal predication. This construction is illustrated in the following:

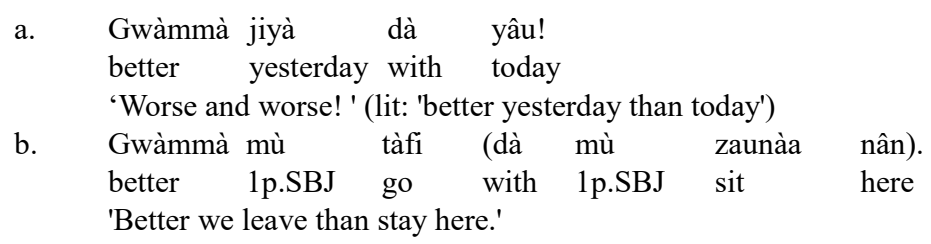

In the examples, the particle gwàmmà can take as complement simple or modified nouns, as in (ia), or propositions, as in (ib). The particle (with its variants like gwamma, gàaràl gaara, gwàddàl gwadda, kwàmmàl kwamma, etc.) introduces the preferred term, while the lesser option is introduced by dà 'with'. In all cases, the expression of the lesser option is optional. Our opinion is that gwàmmà (and its variants) is simply a preposition also functioning as a conjunction. We agree nonetheless that defining what is a full (non-verbal) predication in a way so as to exclude sentence fragments can be a complicated task (see an attempt in Creissels 2006: 344). 
deictic identification, distinguishing it from the two-term "NP1 + NP2 + nee/ cee" sentences, in particular the two-term equative predication.

\section{The one-term deictic identification predication in Hausa.}

This section builds on an idea suggested in Stassen (1997) and taken up by Abdoulaye (2007) in his account of focus constructions in Hausa. Indeed, the section argues for the existence of a basic type of nominal sentences that have the structures "NP + nee/ cee", i.e., these sentences appear to have only one argument. We believe that these sentences, in their basic use, serve for the identification of referents visible in the immediate spatial environment of the speaker. In this basic use, the referent is unmediated by an NP in the sentence before the act of identification. For this reason, we refer to these constructions as "one-term deictic identification" sentences. Since figuring out the identity of a referent is the purpose of the construction, we use the term "identification", instead of "equation", "equative", or any of the terms used for the types of constructions presented in Section 2.

The section starts by illustrating the basic use of the sentences (Section 3.1). The section then reviews some arguments in support of the proposal (Section 3.2-3.4). The section also gives some extended uses of the deictic identification sentences beyond their basic deictic use (Section 3.5). The last subsection (Section 3.6) compares the deictic identification sentences with other NVPs taking only one NP argument and a predicate.

3.1 Basic use of the one-term deictic identification sentences. Stassen (1997: 100ff) distinguishes two fundamentally different types of nominal identification predications: a one-term predication, which he calls "presentation identification" and the ordinary two-term predication. Abdoulaye (2007: 245) adopted this distinction while discussing the Hausa focus construction, which he argued, uses the one-term identification construction to mark the focused phrase (see also Section 3.3 below). Abdoulaye (2007) refers to the one-term identification as the "deictic identification" construction, because it basically serves to directly identify non-discursive entities that are present in the immediate utterance context. Some examples are given in the following (for more examples that can be interpreted as one-term deictic identification sentences, see also Caron 1991: 124, 125; Jaggar 2001: 459, Newman 2000: 161, Wolff 1993: 494):

(13) a. $\begin{aligned} & \text { Abdù nee. } \\ & \text { Abdu COP } \\ & \text { 'It's Abdu.' }\end{aligned}$
b. $\begin{aligned} & \text { Wàa-nee (nèe), cân? } \\ & \text { who-COP COP there } \\ & \text { 'Who is it, there?' }\end{aligned}$

The basic one-term deictic identification predication is illustrated in (13a), an utterance that can be a reply to the question in (13b), which is also a deictic identification clause. In both cases, there is only one NP and the copula nee/ cee (which can be repeated in wh-questions; cf. Caron 1991: 75). Sentences like (13a) are not restricted to being answers to direct identification questions. Indeed, someone can enter or be found in some place (or somehow come to the attention of the interlocutors) and be identified or introduced using (13a), as one would do with the English equivalent. Indeed, as the glosses show, the Hausa one-term construction is the equivalent of English so-called "truncated cleft" construction, where the dummy pronoun it is considered to be the subject in a formally twoterm equative construction (see Mikkelsen 2005: $120 \mathrm{ff}$ and the references she cites). Despite the 
fact that in Hausa there is no such dummy pronoun, the constructions in (13) have nonetheless also been reduced to basic two-term constructions, with an understood recoverable subject term. This reductionist point of view is most clearly expressed in Wolff (1993: 494) for whom the structure "NP + nee/ cee" is basically a two-term structure "NP1 + NP2 + nee/ cee" (see also Jaggar 2001: 459). In the same vein, Caron (1991: 21, 125) states that the subject term (NP1) of the nominal predication "NP1 + NP2 + nee/ cee" "may fail to appear when the situation itself is the subject of the predication or when it [the subject] is evident" (NB: our translation). Indeed, according to Caron (1991: 125), in (13a), the NP Abdù is the predicate while the subject is the context of the predication, even if the position is syntactically empty. He believes that this analysis is supported by the fact that the empty subject position can optionally be filled with a demonstrative pronoun or expression, as illustrated in the following:
a. Wa-n-càn Abdù nee.
one-DF-there Abdu COP
'That is Abdu.'
b. (Abû-n ga) wa-ni yaaròo nee. thing-DF here one-3ms boy COP
'Once upon a time there was a young man.

In (14a-b), the demonstrative pronoun and the demonstrative expression, by all accounts, are the subject of their predication (according to Caron 1991: 125, sentence (14b) is typically used to introduce the main participant at the beginning of a story). While we accept that sentences (13a) and (14a) are equivalent in their usage, we claim that they do not have the same structure, at the syntactic or logical levels. Sentence (13a) has only one term, while (14a) and similar sentences with two nouns, such as those in (4), are two-term equative predications.

As an anonymous reviewer noted, assuming a basic one-term deictic identification cannot however exclude the fact that deletion processes happen in NVPs, just as they happen in verbal predications. Here are some examples discussed by Green (2004: 19, 20, 25):
(15) a. Abdù nee dàaraktàa.
Abdu COP director
'ABDU is director.'
b. Aa'àa, ita cèe.
No 3 fs $\mathrm{COP}$
'No, SHE is.'

(16) a. Mùtumì-n cân likitàa-naa nèe.

man-of there doctor-of.1s COP

'That man over there is my doctor.'

b. Mùtumì-n cân nee.

man-of there COP

'(He) is that man over there.'

c. Likitàa-naa nèe.

doctor-of.1s COP

'(He) is my doctor.' 
Sentence (15a) illustrates a nominal predication where the subject, $A b d \grave{u}$, is focus-fronted and marked with copula nee/ cee (glossed in the original as "FM", for "focus marker", by Green; see comments of Table 2). Sentence (15b), denying (15a), states that another person is director, but with ellipsis of the nominal predicate dàaraktàa 'director' (for other illustrative cases of ellipsis in NVPs see Jaggar 2001: 439, 505 and Tuller 1986: 187, 190). The case of data (16) is more complex. According to Green (2004: 20), given the full equative sentence in (16a), it is possible to omit one or the other NP, as seen in (16b-c). It may be noted though that sentences (16b-c) do not answer the same question. Sentence (16b) would be a good reply to the two-term specification question wàanee nèe likitànkà? 'who is your doctor?', in which case it would indeed be an elliptical structure (or a "pro drop" structure, in the generative terminology). Sentence (16c), on the other hand, can answer the one-term deictic identification question wàanee nèe, cân? 'who is it, there?', in which case it would be an instance of the one-term deictic identification. In sum, there are genuine cases of elliptical structures in NVPs that must be distinguished from the basic one-term deictic identification constructions.

In the remaining subsections, we provide more evidence in favor of establishing the oneterm deictic identification as a basic NVP independent from the two-term non-verbal sentences.

3.2. Distinctive copulas for the two constructions. The clearest indication of the basic status of the one-term deictic identification relates to dialectal facts in Hausa. Indeed, while all dialects use the same copula nee/ cee (or its variant naa/ taa in western dialects) in assertive contexts, the situation is different when it comes to non-assertive contexts. Indeed, for non-assertive contexts, there is a split between central and eastern dialects, which use the same replacive copula for the deictic and the two-term specificational or equative constructions, and the western dialects which use two different copulas, one for the deictic identification and another for the two-term specification or equative constructions. This is illustrated in the following data, contrasting the two groups of dialects in non-assertive sentences (the central/ eastern dialects are illustrated in (17) and the western dialects in (18)):

$\begin{array}{lllll}\text { a. Paarìs } & \text { cee } & \text { kèe } & \text { bàbban birni-n } & \text { Fàransà. } \\ \text { Paris } & \text { COP } & \text { COP } & \text { capital-of } & \text { France }\end{array}$

'It is Paris that is the capital city of France.'

b. Paarìs kèe nan!

Paris COP there

'It is Paris!' (i.e., 'This is the Paris you've heard so much about.')

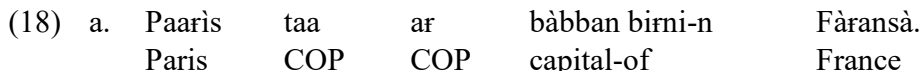

'It is Paris that is the capital of France.'

b. Paarìs kèe nan! (= Paarìs kèe ga $)$

Paris COP there Paris COP here

'It is Paris!' (i.e., 'This is the Paris you've heard so much about.')

Sentences (17) show that the central/ eastern dialects use the same replacive copula kèe 'be' for the two-term specification sentence in (17a) and the deictic identification sentence in (17b). It may be recalled that copula kèe marks the part of an utterance that is presupposed (such as the presupposed causal and consequent adverbial clauses, the relative clauses, and the out-of-focus clauses of constituent focus and wh-questions). Thus, in (17a) the nominal Paaris 'Paris' is focused, and the 
rest of the sentence is out of assertion (see the pragmatically neutral version with copula nee/ cee in data (4a) above). In (17b), although there is no focused element, the statement presents the city of Paris to an interlocutor who, to a certain extent, already knows Paris for having heard so much about it (cf. the pragmatically neutral, fully asserted Paaris cee 'it is Paris'; but see Jaggar 2001: 463 and Newman 2000: 547 for two different views). Although sentences such (17b) are used to complete the identification of entities, they still have an element of presupposition in them (since the listener already knows about Paris, a situation that is precisely taken into account by the speaker). For this reason, we will refer to them as "non-assertive deictic identification" and align them with the other presupposition contexts (i.e., the causal or consequent adverbial clauses, the relative clauses, and the out-of-focus clauses of constituent focus and wh-questions). Kèe is originally a locative copula, which explains why it is accompanied with the demonstrative nan 'there' (see Jaggar 2001: 463 who refers to the whole kè nan expression as a "copular phrase"). Example (18a) shows that in western

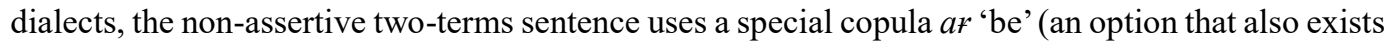
for the central dialects). By contrast, example (18b) shows that western dialects use the same kèe nan copula as the central/ eastern dialects for the one-term deictic identification. Data (17-18) thus show that the one-term deictic identification cannot be reduced to a two-term specification or equative sentence whose subject would be understood or deleted (for a similar use of the existence of differential copulas as argument for distinguishing types of predications see also Hengeveld 1992: 81-83 and Roy 2013: 28ff). It may be noted that when the (to be) identified entity is referred to with the demonstrative pronoun wancàn 'that/ that one', as is illustrated in (14a), then the corresponding non-assertive sentence must use the copula ar in western dialects, as illustrated next using focalization: ${ }^{3}$

$\begin{array}{llll}\text { Wa-n-càn } \quad \text { naa } & \text { ar } & \text { Abdù! } \\ \text { one-DF-there COP } & \text { COP } & \text { ABdu } \\ \text { 'It's that one that is Abdu!' } & & \end{array}$

Sentence (19) is the focused version of sentence (14a) (or, more precisely, of its western dialect version wancàn Abdù naa 'that is Abdu', using the western copula naa/taa) and, as can be seen, it requires the copula $a r$. This shows that in sentence (14a) the demonstrative pronoun is not optional, and the sentence is a two-term equative predication. Even if the contrast observed in (17-18) is quite strong, it may nevertheless be noted that the copula af can appear in one-term identification, but only with a meaning akin to 'it is finished', as illustrated next (we thank Mr Aminou Yawale for drawing our attention to example (20c)):

\footnotetext{
3 The western Hausa copula that we represent graphically as af is phonetically [?áC], i.e., with an initial glottal stop and a final consonant that always assimilates to the next consonant. Given its dialectal and domain restriction, it is probably a new copula. Like copula -nàa or kèe/-kè, af might have started in western dialects as a locative copula in non-assertive contexts when a subject is relativized, focus-fronted or questioned in nonverbal predications (cf. Abdù naa ar cikin daakii 'it is Abdu that is in the room'), thus displacing the pandialectal non-assertive copula kèe/-kè in these contexts. Kèe/-kè is still used in western dialects in presupposed reason and consequence adverbial clauses, in out-of-focus clauses of non-subject relative, nonsubject focus, and non-subject wh-question constructions, and in one-term non-assertive deictic identification, as seen in (18b). Possible sources for ar may include the dismissive expression (kài) ar! 'blast you', also used as $a f$ ! or as! to chase animals away, specially the hens. In this case, it may well link up with the verb yar/ yas 'throw away' (pronounced with a palatal approximant [j] or a laryngealized [j]), which itself is a short version of the causative iyar dà [?íjár dà] 'finish off, do away with' based on the verb yi/i ([jí]/ [?í]) 'do' (for a summary on the origin of copulas in languages see Pustet 2003: 54-61).
} 
(20) a. Shii kèe nan!
$3 \mathrm{~ms}$ COP there
'It's over/ done; that is it!'

b. Ita ar nan!

$3 \mathrm{fs} \quad \mathrm{COP}$ there

'It's over/ done; that is it!'

c. Làabàaru-n duuniyàa kèe nan ar nan!

news-of world COP there COP there

'That was the international news [you just listened to]!'

In the discussion of (17b), we said that the sentence expresses the non-assertive one-term deictic identification. However, the construction has also given rise to a fixed expression using the third person masculine pronoun shii with an impersonal sense, as seen in (20a), whereby a speaker acknowledges the end of an event, especially if the end is sudden or accidental (for example, any sports match quickly concluded; cf. French ça y est! 'it is good/ fine/ it is all over'). Sentence (20a) is pandialectal, but the western dialects also have an alternative form using the third person feminine pronoun ita with an impersonal sense and the copula ar, which is augmented with the demonstrative adverb nan 'there', certainly by analogy with kèe nan. The example in (20c) is a particular mannerism of a journalist from the Deutsche Welle Hausa section, who so concludes his international newscast, marking twice the meaning 'it's over' by combining the pan-dialectal copula kèe nan and the western Hausa copula af nan. The examples (20b-c) clearly have a marginal status in the western dialects and one may note that copula ar cannot mark the true non-assertive deictic identification (and hence cannot replace kèe nan in example (18b) above). ${ }^{4}$

The argument based on the existence of distinctive copulas for both types of predications can be extended to the locative copula -nàa 'be.LOC'. Indeed, locative -nàa can be recruited to express two-term non-verbal sentences; but apparently it cannot be recruited to express the one-term deictic identification. These points are illustrated in the following (for data similar to (21a-b) see also Jaggar 2001: 473, Wolff 1993: 428):
a.
Muusaa ya-nàa
Musa 3ms-C
soojà
a-kà
kaamàa shi.
'Musa was a soldier when he was arrested.'
b. Muusaa ya-nàa kàramii mu-kà zoo nân.
Musa 3ms-COP little 1p-RP come here
'Musa was a child when we came here.'
c. Ta-nàa màata-r-kà bà zaa kà cêe bâa ruwa-n-kà ba. 3 fs-COP wife-of-2ms NEG FUT 2ms say exist.NEG concern-of-2ms NEG '[Since] she is your wife, you can't stay unconcerned.'

\footnotetext{
4 Another sign of the marginal status of (20b) in western dialects is the fact that the utterance cannot be negated (cf. *bà ita ar nan ba 'it is not over, it is not finished'). By contrast, sentence (20a), with copula kèe/-kè, can be negated in all dialects as bàa shii kèe nan $b a$ 'it is not yet over, it is not yet finished'. Naturally, ar itself can be negated in non-assertive nominal predication as in bàa Landàn ar bàbban birnin Fàransà ba 'it is not London that is the capital city of France'.
} 


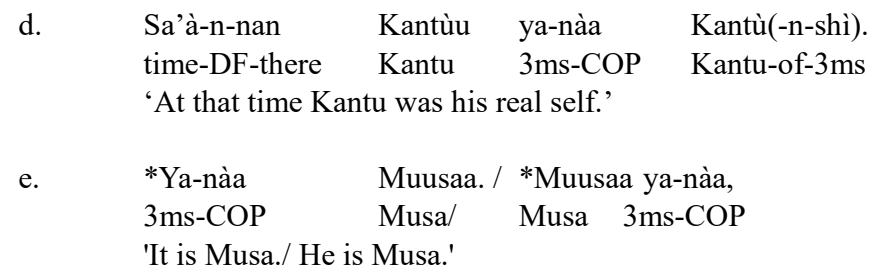

Sentences (21a-b) illustrates, respectively, a nominal and an adjectival predication. Sentences (21c-d) illustrates, respectively, a specificational sentence and an identity statement (Kantu was a famous Nigerien wrestler who eventually retired). As can be seen, copula -nàa is felicitous in all these sentences. However, sentence (21e) shows that it is not possible to use copula nàa in a one-term deictic identification, no matter the ordering of the copula and the single term. It should be noted that -nàa is basically a locative copula, which therefore has apparently begun encroaching on the domain of copula nee/ cee, but is limited, for the moment, to two-term non-verbal sentences. It may also be noted that the use of -nàa in nominal sentences usually describes past situations (though see (21c); see also Newman 2000: 578). The copula nee/ cee has no such restriction. Apart from Hausa, the specialization of the copulas for one-term or two-term predications is also verified in other African languages, such as Zarma, Fon (Gbe), Nupe, or Wolof (see the discussion in the next subsection).

3.3 Use of deictic identification construction in focus-fronting. Another reason for considering one-term deictic identification sentences as an independent type of predication is the fact that it alone seems to have a derivative use in focus constructions. Indeed, many authors, while adopting the reductionist approach, nonetheless note that in many languages it is the deictic identification structure that is used to mark a focus-fronted constituent. For example, Creissels (2006: 357) claims "In many languages, the constructions used to express the identification of the referent of a noun [i.e., the deictic identification], as illustrated in [(22)], are also the basis of constructions used to make explicit the utterance value of declarative sentences [...], as illustrated in [(23b)], or constructions used to focus a nominal or an adpositional constituent, as illustrated in [(24)]". [NB: our translation.] Creissels gives the following examples:
a.

$\begin{array}{llll}\text { Les } & \text { enfants } & \text { sont } & \text { bien } \\ \text { DET.p } & \text { children } & \text { COP } & \text { well }\end{array}$
en retard.
'The children are very late.'
b. (Ce qui se passe) c'est qu'ils ont manqué le bus. that thathappen it COP that $3 p$ CPL miss DET.s bus 'What happened/ it is that they missed the bus.'

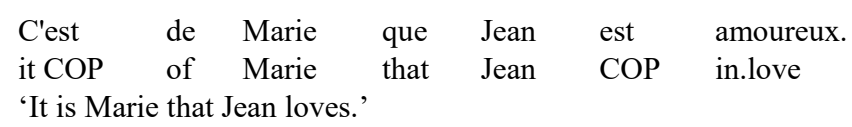

Creissels apparently assumes that sentence (22) is a two-term equative predication, with an optional explicit subject (ce garçon), the dummy subject ce 'it', the copula être 'be', and the complement 
noun (Jean). The same dummy subject and its copula are used to mark sentences, such as (23b), that provide an emphatic explanation (to a previously stated or observed situation, such as in (23a)) and which are the equivalent of English wh-cleft constructions. Clearly, the presentation of the example suggests a structural parallel with the presumed equative sentence (22), with an optional explicit subject referring to a situation (ce qui se passe), the dummy ce, the copula, and a propositional complement. Finally, according to Creissels, in (24) the same dummy ce and the copula être 'be' are used to mark a focus-fronted constituent, which is followed by an out-of-focus clause containing an empty constituent co-indexed with the displaced phrase. Here however, an optional explicit subject is not possible and only the dummy ce appears with the copula. For languages like French or English that use dummy pronouns, one may still fairly establish - if only formally - an equation between the dummy subject and the fronted phrase. But many languages do not use a dummy pronoun in their focus constructions. Hausa is one such language, as illustrated in the following:
a. Abdù
COP one-RP
Abdu
see
nee a-kà
ganii
'It was Abdu that was seen at the market.'
b. An ga Abdù kàasuwaa.
one.CPL see Abdu market
'Someone saw Abdu at the market.'

kàasuwaa.

market

In (25a), the nominal Abdì is fronted out of the direct object position and marked with the copula nee/ cee (cf. the non-focused version in (25b)). Although there is no dummy pronoun in (25a), Caron (1991) nonetheless proposes an equation analysis for similar sentences, giving two alternative solutions. First, the equation can be established between the fronted nominal Abdù and its empty direct object position in the out-of-focus clause (see Caron 1991: 21). Secondly, the equation can be established between the focused nominal $A b d \grave{u}$ and the entire situation described by the out-of-focus clause, which would be the subject term of the equative sentence (see Caron 1991: 22).

In this subsection, we naturally agree with the proposal that the deictic identification construction is recruited to mark focus-fronted constituents. However, according to Abdoulaye (2007: 246), the clearest indication of the involvement of the deictic identification construction is to be found in examples where the out-of-focus proposition has no empty or understood argument that could be co-indexed with the focused phrase. This is illustrated in the following data:
a.
$\begin{array}{lll}\text { Hàukaa } & \text { nèe } & ((,) \text { dà }) \\ \text { madness } & \text { COP } & \text { that }\end{array}$
ka-kèe
bugar ma-nì daa?
'Are you crazy, to hit my child?'
b. Shùugàban kasaa nèe ((,) dà) mu-kèe jîn jìiniyàa dâazu. president COP that 1p-RI hear siren a.while.ago 'It was the president (who was passing) when we heard a siren earlier.'

\begin{tabular}{|c|c|c|c|c|c|c|}
\hline $\begin{array}{l}\text { Dà } \\
\text { that }\end{array}$ & $\begin{array}{l}\text { ka-kèe } \\
2 \mathrm{~ms}-\mathrm{RI}\end{array}$ & $\begin{array}{l}\text { bugar } \\
\text { hit }\end{array}$ & $\begin{array}{l}\text { ma-nì } \\
\text { to-1s }\end{array}$ & $\begin{array}{l}\text { daa, } \\
\text { son }\end{array}$ & $\begin{array}{l}\text { hàukaa } \\
\text { madness }\end{array}$ & $\begin{array}{l}\text { nèe? } \\
\text { COP }\end{array}$ \\
\hline
\end{tabular}

According to Abdoulaye (2007), in examples (26-27), the italicized constituents are focalized (with emphasis) against background subordinate adverbial clauses that carry presupposed information and are marked as such by the non-assertive copula kèe/-kè (functioning here as an imperfective 
auxiliary). As may be seen in (26), the out-of-focus proposition can optionally be introduced by the subordinating conjunction $d \grave{a}$, which may or may not be preceded by a pause. When the conjunction (and the pause it licenses) is omitted, then one formally obtains nearly typical Hausa focus-fronting constructions. In the alternative (and in fact more basic) construction illustrated in (27), the out-offocus proposition can precede the focused constituent, but in this case the subordinating conjunction $d \grave{a}$ is required and a pause must separate off the focused constituent. It should be noted that if the adverbial clauses in (26-27) are omitted, one then obtains simple deictic identification clauses. All these facts point to the relative syntactic independence of the deictic identification "NP + nee/ cee" predication proper in example (26-27). Also, it is probably not possible to establish in sentences (26-27) a coreference between the focused constituents and anything in the out-of-focus adverbial clauses. Indeed, none of the out-of-focus clauses contains an empty position that can be equated with the focused constituent. Similarly, there certainly can be no equation between, say, the referent of shùugàban kasaa 'president' in (26b) and the event of hearing the sirens. Rather, the president is emphasized as the cause for hearing the sirens (i.e., one explains the other).

Apart from Hausa, in other African languages where one-term deictic identification and two-term non-verbal predictions use distinctive copulas, it is the deictic identification copula that is used in focus-fronting constructions, not the copula of the two-term constructions. As noted in Abdoulaye (2007: 247n4), Zarma (Songhay) has two copulas $t i$ 'be' and $n o ̂$ 'be'. In positive deictic identification and in focus constructions only nôo appears (see Sibomana 1995: 39), whereas in the negative versions of these constructions the two copulas $t i$ and nô are required (see Sibomana 1995: 39, 44). However, in two-term positive nominal and equative predications, copula $t i$ is preferred but noo is also possible (see Sibomana 1995: 52n1). On the other hand, in two-term negative nominal and equative predications, only copula $t i$ is possible. In spite of the multiple overlaps, it is clear that in Zarma copulas are sensitive to the type of predication involved. Similarly, in Fon (Gbe) the same copula is used for deictic identification and in focus-fronting (see Ndayiragije 1992: 64 and Lefebvre 1992: 54n2), whereas a different copula is used in two-term nominal predication (see Ndayiragije 1992: 67). Creissels (1978: 137f) also points to a link between a focus marker and a deictic identification copula in Nupe and Wolof. It can be concluded that the deictic identification construction is fundamentally different from the two-term nominal predication and on this basis many languages select it to mark focus-fronted constituents.

3.4 Syntactic contrast between focus or wh-constructions with and without copula nee/ cee. In Hausa, as in many other languages (see Schachter 1973), wh-questions typically share some formal characteristics with focus (and with relative) constructions. Indeed, like the focused constituents seen in Section 3.2, wh-words in Hausa are fronted and followed by the copula nee/ cee, and then by the out-of-focus clause. Although we have nearly consistently illustrated the focus constructions in Section 3.2 with the copula nee/ cee, in fact the copula is optional, for both focus and wh-question constructions. This subsection shows that in both constructions, when the fronted constituent is followed by the copula, the two seem to form a one-term predication, and the so-formed predication is syntactically freer from the following out-of-focus clause, then would be an unmarked fronted constituent. But first, let us illustrate next the two constructions, with and without the copula:

(28) a. Abdù a-kà ganii $-\begin{aligned} & \text { kàasuwaa. } \\ & \text { market }\end{aligned}$
'Abdu one-RP see 
b. Abdù nee a-kà ganii_kàasuwaa.

Abdu COP one-RP see market

'It was Abdu that was seen at the market.'

(29) a. Wàa a-kà ganii _ kàasuwaa?

'Who was seen at the market?'

b. Wàa-nee nèe a-kà ganii _ kàasuwaa?

who-COP COP one-RP see market

'Who was it who was seen at the market?'

As shown in Abdoulaye (2007), there are many different pragmatic implications between presence and absence of the copula in fronting constructions. For example, sentence (28a), without the copula, implies a strong contrast between Abdu and another person that was incorrectly held (by the listener) to validate the predication. Sentence (28b), with the copula, has no contrast but emphatically identifies Abdu as the person seen at the market (say, after people long wondered who was seen at the market and the speaker found out the information). In sentence (29a), without the copula, the speaker does not rule out that the wh-pronoun refer to a null set (i.e., nobody relevant was seen at the market). By contrast, in sentence (29b) the speaker assumes someone relevant must exist that was seen at the market (see Abdoulaye 2007 for more details on these contrasts; see Dryer 1996: 486ff for the interpretation of English wh-words with or without a copula; see also the comments around Table 2). Besides these pragmatic differences, the fronted constructions in (28b) and (29b), with copula nee/ cee, show more syntactic flexibility than the corresponding constructions in (28a) and (29a), without the copula. This is illustrated next with an insertion test:

a. *Abdù, har dà ya-kè bâ ni dà tabbàt, a-kà Abdu even that 3ms-COP NEG 1 s have certainty one-RP cêe yaa gudù

say 3ms.CPL run

'??ABDU, although I have no confirmation, was said to have fled.'

b. Abdù nee, har dà ya-kè bâ ni dà tabbàt, a-kà cêe yaa gudù. Abdu COP even that 3ms-COP NEG 1s have certainty one-RP say 3ms.CPL run 'It's Abdu who, although I have no confirmation, was said to have fled.'

(31) a. *Wàa, duk dà bâ-i sô, ya tàfi kàasuwaa? who all that NEG-3ms.IPF want $3 \mathrm{~m} . \mathrm{RP}$ go market '*Who, although he didn't like it, went to the market?'

b. Wàa-nee nèe, duk dà bâ-i sô, ya tàfi kàasuwaa? who-COP COP all that NEG-3ms.IPF want $3 \mathrm{~m}$.RP go market 'Who is it who, although he didn't like it, went to the market?'

It may be noted that in all four sentences in (30-31), the fronted constituent is co-indexed with the subject pronoun ( $y a a^{\prime}$ ' $3 \mathrm{~ms}$.CPL' in (30) and $y a$ ' $3 \mathrm{~ms}$. RP' in (31)) in the (main) out-of-focus clause. Nonetheless, it is only when the fronted constituent has an accompanying copula that parenthetical material can be felicitously inserted, as seen in (30b) and (31b) (dialectal evidence suggests that when the $w h$-word has two copulas, as is the case in $(31 \mathrm{~b})$, the first one is the oldest and likely fused with the pronoun, with the second copula probably being a reinforcement; see Caron 1991: 75 for 
the relevant dialectal data). We believe that these facts are more consistent with an analysis of sentences (30b) and (31b) as having incorporated a one-term identification predication. In other words, sentences (30a) and (31b) are structurally different and the copula in (30b) is more than an appendage marking the fronted constituent (see more on this in the comments around Table 2). The reductionist approach would probably not have much to say about the contrast between these sentences. The next subsection focuses on other derived uses of the deictic identification predication.

3.5 Other uses of the one-term deictic identification predication. As can be expected with a basic structure, the deictic identification construction, apart from its use in focalization, has other extended or derived uses, where sometimes the external utterance context is not directly referred to. Here are some examples (example (32a) adapted from Beik 1987: 194 and (32b-d) from MoussaAghali 2000: 42, 34, 28):

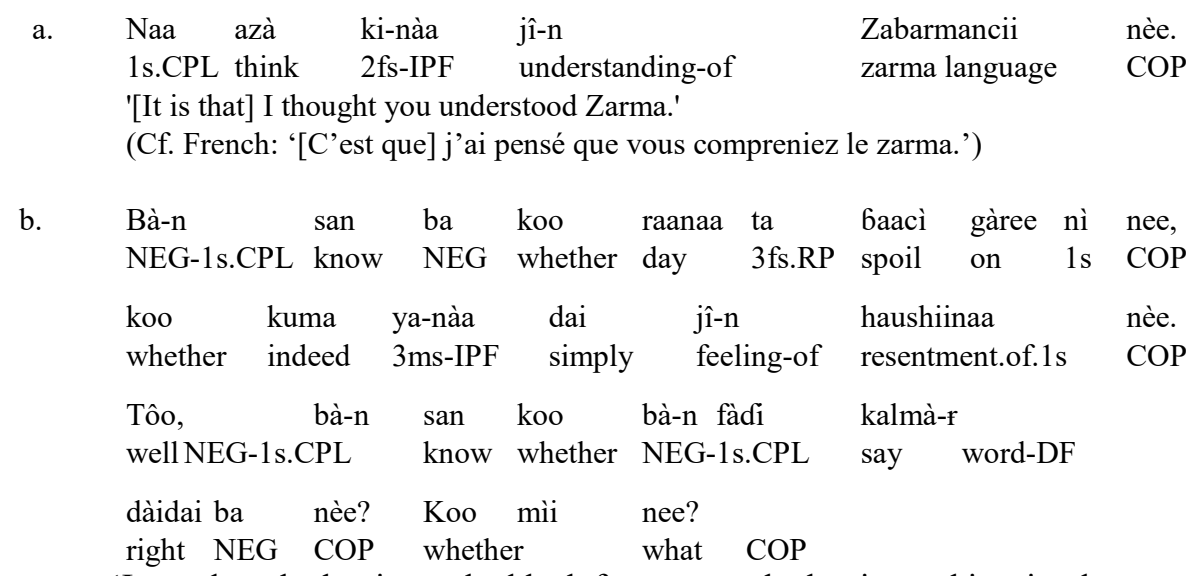

'I wonder whether it was bad luck for me, or whether it was him simply resenting me. Well, I wonder whether it was that I did not repeat the word correctly. Or whatever it was.'

c. Tôo, shii kèe nan.

well, $3 \mathrm{~ms}$ COP there

'Well, that's all / it's over / we're set / etc.'

d. In lookàci-n aduwàa dà magaryaa nèe kuma, sai mù

if time-of aduwa.fruit and magarya.fruit COP indeed, then 1p.SBJ

jee kaada-r yaayân-n.

go harvesting-of fruits-DF

'When it is desert date and jujube fruits season, we would then go harvest them.'

e. Màalàmai nèe, Kiristàa nee, 'yan bòorii nèe, koowaa

Muslims COP Christians COP Bori followers COP everybody

ya-nàa tàfiyàa wuri-n ròoko-n ruwaa.

3ms-IPF go place-of prayer-of rain

'Whether Muslims, Christians or Bori followers, everybody attends the rain prayers.'

(Cf. French: 'Que ce soit les musulmans, que ce soit les chrétiens,,,')

Examples (32a-b) illustrate the emphatic explanation sentences already presented for French in (23b) and which clarify a previously stated or observed situation (see also Wolff 1993: 495). So, in (32a) 
the speaker is trying to explain why he rushed speaking Zarma to the interlocutor. In (32b) the narrator weighs several explanations for the behavior of a narrative participant (a teacher that punished the narrator). Sentence (32c) illustrates a derived use of the deictic identification constructions with the non-assertive copula kèe nan, whereby it expresses the completeness, the completion, or the end of an event, as indicated by the possible translations (see also the discussion of (20a-b) above). In (32d) the single term of the predication is a complex NP and the whole predication is introduced by the conditional conjunction in/idan 'if'. Finally, sentence (32e) presents a series of one-term identification predications enumerating the elements of a category of people (the involved religious groups).

3.6 Logical structure and syntax of deictic identification. In the previous subsection, we have tried to show that one-term deictic identification and two-term specification or equative sentences are two fundamentally different constructions, based on their morphosyntactic properties. Assuming a distinction between a syntactic level and a logical level for NVPs (see, amongst others, Creissels 2006: 343, den Dikken 2006: 8, 25), this subsection tries to address the issue of the syntactic and logical/ semantic statuses of the single term of a deictic identification construction, compared to the statuses of the two NPs in a two-term specification or equative construction. First, regarding the surface syntax, one may wonder whether the single NP of a one-term deictic identification is the subject or the complement of the predication. In this respect, it may be noted that the single NP of a "NP + COP" deictic identification shares at least one syntactic property with the NP2 of a two-term "NP1 + NP2 + COP" specification or equative construction. Indeed, the NP closest to the copula (whether single NP or an NP2) can shift some of its material to the right of the copula, in an extraposition-like process. This is illustrated in the following:

$\begin{array}{llllll}\text { a. Abdù } \quad \text { [ùba-n } & \text { Muusaa } & \text { na } & \text { gàske] } & \text { nèe. } \\ \text { Abdu } \quad \text { father-of } & \text { Musa } & \text { one.of } & \text { truth } & \text { COP } \\ \text { 'Abdu is Musa's real father.' } & & & \\ \text { = Abdù ùba-n Muusaa nèe na gàske. } & & & \end{array}$

b. [Daalìbâ-r dà mu-kèe jiràa $]$ cee. student-DF that $1 \mathrm{p}-\mathrm{RI}$ wait COP

'It is the student we have been waiting for [while introducing a person].'

$=$ Daalibâr cee dà mu-kèe jiràa.

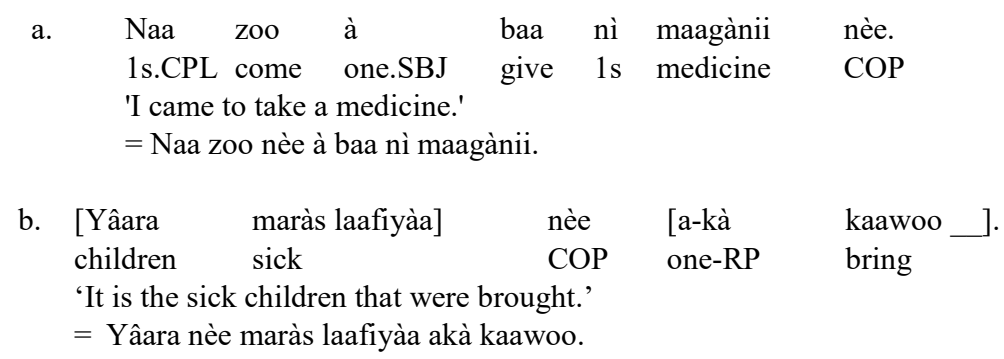

Sentences (33a-b) show, respectively, that the NP2 of an equative sentence and the single NP of a deictic identification can shift a sub-constituent after the copula nee/ cee (see also the discussion in Jaggar 2001: 460, Newman 2000: 167). The same material shifting is also possible for some of the derived uses of the one-term deictic identification, as seen in data (34a-b) illustrating, respectively, a sentence expressing an emphatic explanation and a sentence with a focus-fronted constituent. These may seem to weaken our analysis which would assume that the single NP of the deictic 
identification predication would be the subject. Yet it behaves like the complement of a two-term specification or equative construction. Conversely, the facts of (33-34) would seem to support the reductionist claim that the single term of the deictic identification is a complement, with an understood subject elsewhere. Nonetheless, our analysis can be maintained if one considers that copula nee/ cee would simply allow any NP that is next to it to shift materials to the right, regardless of its function, subject or complement. Also, according to Payne (1997: 114) even in two-term equative and identity statements, it is not easy to determine what is the subject and what is the complement, given the equivalence between the two terms, which often results in their interchangeability.

Secondly, regarding the logical semantic level, one may wonder whether the single NP of a deictic identification predication is the logical predicate or the logical argument. We propose that the one-term analysis of deictic identification predications also extends to the logical level. In this case, the single NP would necessarily be a logical argument, with the copula assuming a predicate function. In this respect, it may be noted that many authors (cf. Roy 2013: 8f, Rothstein 2001: 240 241, see also Heycock and Kroch 1999 and the other references cited in Mikkelsen 2005: 43f) do not consider that the two terms of ordinary specificational and equative clauses are in a logical subject/ predicate relationship. Instead, they argue that the two terms of an equation have the same syntactic category, the same semantics, and none of them refers to a property that would make it a predicate (see the discussion in Hengeveld 1992: 54 on the semantics of nominal predicates). Consequently, many researchers consider equative constructions to have the structure of ordinary transitive clauses, with a copula-verb (if the language uses one) and its two arguments, where the copula provides the "semantic glue" (see Mikkelsen 2005: 49f; for a contrary view, see den Dikken 2006: 76). Assuming these proposals, we consider that the logical structure of a deictic identification predication in Hausa is simply "BE (x)", where the predicate "BE" is the assertive copula nee / cee or the non-assertive copula kèe/-kè and the " $\mathrm{x}$ " the single NP that references a real world entity. This structure would be similar to other non-verbal predications with a single subject term and a copular predicate, such as the existential predication ("EXIST (x)"; as in àkwai Abdu 'Abdou exists'/ bâa Abdù lit. 'Abdu does not exist', i.e., 'Abdu is dead'), and, particularly, the presentational predication ("HERE IS (x)"; as in gàa Abdù 'here is Abdou'). Given their substantial, specific semantics, the existential and presentational predicates can easily be conceived as logical predicates. By contrast, one must assume some flexibility with the status of copula nee/ cee or kèe/-kè. In nominal or adjectival predications with two terms, one term is subject, and the other is the logical predicate, linked together by semantically weak nee/ cee or kèe/-kè copulas. But in equative and deictic identification sentences, the copulas nee/ cee and kèe/-kè would automatically become logical predicates, each with a special pragmatic (assertion vs. presupposition) marking function. In any case, one must assume that the minimal semantics of nee/ cee and kèe/-kè in one-term predication is enough to contrast it to the existential and presentational predicates, which also have one term. Considering that copulas nee/ cee and kèe/-kè have some minimal semantics would also be more compatible with the derived uses of the deictic identification seen in Sections 3.3 and 3.5, or the auxiliarization of the copulas into tense/ aspect markers (for a plethora of secondary uses of the copula kè nan see Jaggar 2001: 463f: see also Pustet 2003: 45-53, 59-61 for the wide range of semantic and functional distinctions marked by copulas in languages).

To summarize, one can distinguish for Hausa (and probably for other languages as well) a deictic identification predication with one NP term from the equative predication with two NP terms. We have shown that this distinction is supported by a certain number of facts, in particular the existence sometimes of different copulas for the two constructions and the derived uses for which 
only the deictic identification predication is recruited. The NVPs in Hausa and their copulas and predicates can be summarized as in the Table 2 .

Table 2: Copulas in Hausa (central and east dialects)

\begin{tabular}{|c|c|c|c|}
\hline & Assertion & presupposition & Negation \\
\hline Deictic identification & nee / cee & kèe nan & \\
\hline Nominal predication & nee / cee, (-nàa) & kèe / - kè & \\
\hline Specification & nee / cee, (-nàa) & kèe / - kè & \\
\hline $\begin{array}{l}\text { Adjectival } \\
\text { predication }\end{array}$ & nee / cee, (-nàa) & kèe / - kè & \\
\hline Localization & -nàa & kèe / - kè & bâa \\
\hline Possession & -nàa dà & kèe dà & bâa ... dà \\
\hline Existence & dà, àkwai, dàkwai & kèe (d)àkwai & bâa / baabù \\
\hline Presentation & gàa & & \\
\hline
\end{tabular}

In Table 2 the "assertion" domain refers to all NVP sentences conveying "neutral", new information (naturally, negative sentences, too, are asserted; but the table sets them off to show their distinctive predicates). As can be seen, nee/ cee spans the range of all "NP1+NP2"-based sentences and adjectival sentences. According to Abdoulaye (2006: 1162, n5, 2007), the deictic identification function of nee/ cee carries over into the grammatical focus constructions, where, depending on the context, nee/ cee can mark the basic deictic identification (see mootàa cee sukèe wankèewaa cân 'it is a/the car that they are washing over there', which can be said when the interlocutors are watching the event, vs. mootàa sukèe wankèewa cân 'They are washing CARS/THE CAR over there', which excludes a direct observation of the event. In focus constructions, copula nee/ cee can also mark functions derived from deictic identification, such as the exhaustive listing function (see muи nèe mukà san Bàmàko 'we are the ones who know Bamako' vs. muu mukà san Bàmàko 'we indeed know Bamako'). For this reason, and following Abdoulaye (2007), nee/ cee is glossed as "COP" in all of its occurrences (in this perspective, the semantic components of "focus", i.e., emphasis and contrast, are marked by the fronting alone). Copula nee/ cee is probably the most problematic copula in Hausa, as seen in the many different labels it has received in Hausa descriptions: "copula" (in most sources, e.g., Wolff 1993: 494), "actualizer" (Caron 1991: 134), and "stabilizer" (Newman 2000: 160). In one particular proposal (Green 1997, 2004, Green and Jaggar 2003), nee/ cee is labeled as a focus marker and glossed "FM" through all of its occurrences on the ground that it marks focus in copular clauses in the same way it does in grammatical focus constructions (in this perspective, "focus" bundles the semantic components of "new information", "exhaustive listing", and "contrast"). Also, most people note the connection between copula nee/ cee, the pronouns na (masculine singular or plural)/ ta (feminine), and the adverbs nân 'here'/ cân 'there' (see Newman 2000: 36, 300, 545). Abdoulaye (2007: 243) specifically proposes that copula nee/ cee derives from former emphasis and contrast markers, which themselves may have derived from pronouns or adverbs (see Stassen 1997: 66f, 80 and Frajzyngier 1985: 66ff on the general idea that copulas can develop from discourse markers). Copula -nàa essentially spans the localization and possessive predications. It also auxiliarized to mark the "general", assertive imperfective in verbal clauses and has a host of other functions that can be derived from its localization function. Nearly all assertivecontext copulas and predicates are replaced by kèe/-kè in non-assertive clauses (except for gàa, the subject of which cannot be focused, and àkwai, which combines with kèe/-kè). ). Copula kèe/-kè has 
also auxiliarized to mark the "relative" imperfective -kèe in non-assertive verbal clauses (it may be noted that for the sake of simplicity, all copulas and predicates are glossed "COP" in the examples, except for kèe/-kè and -nàa when they occur as auxiliaries, in which case they are glossed as tense/ aspect markers; for a full account of tense/ aspects categories in Hausa see, amongst others, Newman 2000: 564-596).

\section{Conclusion}

General works (Payne 1997, Creissels 2006, Declerck 1988, Pustet 2003, etc.) have explored the many facets of non-verbal predication in languages and their importance in language description. This article shows that the NVPs types can be enriched with a new basic type: the deictic identification predication. This type of NVP stems from the distinction made between an ordinary equative sentence and a one-term identification predication. The article has shown that the two types of clauses select different copulas in non-assertive contexts in the western dialects of Hausa. The article has also shown that the deictic identification has derived uses for which the two-term equative predication is not recruited.

\section{List of Abbreviations}

$\begin{array}{ll}1 / 2 / 3 & 1^{\text {st }} / 2^{\text {nd }} / 3 \text { rd person } \\ \text { COP } & \text { copula } \\ \text { CPL } & \text { Completive } \\ \text { DET } & \text { determiner } \\ \text { DF } & \text { definiteness marker } \\ \text { f } & \text { feminine; } \\ \text { FUT } & \text { Future } \\ \text { IPF } & \text { Imperfective } \\ \text { LOC } & \text { locative } \\ \text { m } & \text { masculine } \\ \text { NEG } & \text { negative } \\ \text { NP } & \text { noun phrase } \\ \text { NVP } & \text { non-verbal predication } \\ \text { p } & \text { plural } \\ \text { RI } & \text { Relative Imperfective } \\ \text { RP } & \text { Relative Perfective } \\ \text { s } & \text { singular } \\ \text { SB } & \text { subjunctive. }\end{array}$

\section{References}

Abdoulaye, Mahamane L. 2006. Existential and possessive predications in Hausa. Linguistics 44, 1121-1164.

Abdoulaye, Mahamane L. 2007. Profiling and identification in Hausa. Journal of Pragmatics 39, 232-269.

Abraham, Roy C. 1959. The language of the Hausa people. London: University of London Press. Beik, Janet. 1987. Hausa theater in Niger: A comtemporary oral art. New York/ London: Garland. Brown, Roger. 1973. A first language: The early stages. Cambridge, MA: Harvard University Press. 
Caron, Bernard B. 1991. Le haoussa de l'Ader. Berlin: Dietrich Reimer Verlag.

Creissels, Denis. 1978. Réflexions au sujet de l'article de Maurice Coyaud: "Emphase, nominalisations relatives"' (La Linguistique, vol.11, fasc. 2/1975). La Linguistique 14, 117 141.

Creissels, Denis. 2006. Syntaxe générale: Une introduction typologique. Paris: Hermes.

Declerck, Renaat. 1988. Studies on copular sentences, clefts and pseudo-clefts. Leuven: Leuven University Press.

den Dikken, Marcel. 2006. Relators and linkers: The syntax of predication, predicate inversion, and copulas. Cambridge, MA: The MIT Press.

Dryer, Matthew S. 1996. Focus, pragmatic presupposition, and activated propositions. Journal of Pragmatics 26, 475-523.

Freeze, Ray. 1992. Existentials and other locatives. Language 68, 553-595.

Garba, Mohammed M., 1989. A new look at the NP+nàà+NP constructions, in: Frajzyngier, Z. (Ed.), Current Progress in Chadic Linguistics. Proceedings of the International Symposium on Chadic Linguistics, Boulder, Colorado, 1-2 May, 1987, Amsterdam: John Benjamins, pp. 121-129.

Green, Melanie. 2004. Predication, Equation and Information Structure: Evidence from Hausa Copular Sentences. Ms, University of Sussex, UK

Green, Melanie. 1997. Focus and Copular Constructions in Hausa. PhD dissertation. School of Oriental and African Studies, London.

Green, Melanie and Philip J. Jaggar. 2003. 'Ex-situ and In-situ Focus in Hausa: Syntax, Semantics and Discourse', in J. Lecarme (ed.), Research in Afroasiatic Grammar, pp. 187-213. Amsterdam: John Benjamins.

Heine, Bernd. 1997. Possession: Cognitive sources, forces, and grammaticalization. Cambridge University Press, Cambridge.

Hengeveld, Kees. 1992. Non-verbal predication: Theory, typology, diachrony. Berlin/ New York: Mouton De Gruyter.

Heycock, Caroline and Anthony Kroch. 1999. Pseudocleft connectedness: Implications for the LF interface level. Linguistic Inquiry 30, 365-397.

Higgins, Francis R. 1979. The pseudo-cleft construction in English. New York: Garland.

Jaggar, Philip J. 2001. Hausa. London Oriental and African Language Library. Amsterdam: John Benjamins.

Lefebvre, Claire. 1992. Towards a typology of predicate cleft languages. Journal of West African Languages 22, 53-61.

Lyons, John. 1968. Introduction to theoretical linguistics. Cambridge: Cambridge University Press.

McConvell, Patrick. 1973. Cleft sentences in Hausa? A syntactic study of focus. Unpublished Ph.D. dissertation, SOAS

Mikkelsen, Line. 2005. Copular clauses: Specification, predication and equation. Amsterdam: John Benjamins.

Moussa-Aghali, F. 2000. Yarintata [My childhood]. Niamey: Editions Albasa.

Ndayiragije, Juvénal 1992. Structures syntaxiques des clivées en fon. Journal of West African Languages 22, 63-95.

Newman, Paul. 2000. The Hausa language: An encyclopedic reference grammar. New Haven: Yale University Press.

Payne, Thomas E. 1997. Describing morphosyntax: A guide for field linguists. Cambridge: Cambridge University Press.

Pustet, Regina, 2003. Copulas: Universals in the categorization of the lexicon. Oxford: Oxford University Press.

Rothstein, Susan. 2001. Predicates and their subjects. Dordrecht: Kluwer.

Roy, Isabelle A., 2003. Non-verbal predication: Copular sentences at the syntax-semantics interface. Oxford: Oxford University Press.

Schachter, Paul. 1973. Focus and relativization. Language 49, 19-46. 
Schachter, Paul. 1985. Parts-of-speech systems, in: Shopen, T. (Ed.), Language Typology and Syntactic Description Vol. 1: Clause Structure. Cambridge: Cambridge University Press. pp. 361.

Sibomana, Leo. 1995. La focalisation en zarma. Afrika und Übersee 78, 39-54.

Stassen, Leon. 1997. Intransitive predication. Oxford: Clarendon Press.

Steinberg, Danny D. 1982. Psycholinguistics: Language, mind, and world. London: Longman.

Wolff, H.E., 1993. Referenzgrammatik des Hausa. Münster/ Hamburg: LIT.

Mahamane L. ABDOULAYE < mlabdoulaye@gmail.com>

Abdou Moumouni University,

Niamey.

Salifou BARMOU < sbarmou@yahoo.fr>

Abdou Moumouni University,

Niamey.

Saoudé SOULEY BIDA < saoudebida@gmail.com>

EUCAP Sahel Niger,

Niamey 